\title{
Kommunikasjon som verktøy i klinisk hverdag
}

\author{
Sviktende kommunikasjon mellom lege og pasient/pårørende er ofte kilde til klagesaker. God kommunika- \\ sjon derimot, er kilde til pasienttilfredshet, bedre helse for pasienten og til mestringsfølelse hos legen. \\ Hvordan kan det legges til rette for at leger får trent opp sine kommunikasjonsferdigheter? Diakonhjemmet \\ Sykehus har valgt å innføre obligatoriske kurs i klinisk kommunikasjon for alle nyansatte leger. Her beskriver \\ vi kurset, implementering og erfaringer fra dette.
}

Dagens pasienter er aktive og medvirkende aktører i egen behandling. Med definerte rettigheter, sterke brukerorganisasjoner i ryggen og økt tilgang på kunnskap om egen sykdom, har pasienten i dag langt bedre forutsetninger for å være aktivt deltakende i egen behandling. Den nye pasientrollen krever omstilling også i legerollen med mer vekt på kommunikasjons- og samhandlingsferdigheter - ferdigheter som må øves opp og holdes ved like gjennom praksis.

Dagens sykdomsbilde med stadig flere som får kroniske sykdommer gir ikke bare pasienten, men også helsevesenet, andre utfordringer som følge av dette. Pasientens evne til å ta vare på egen helse, kanskje også være sin egen behandler, slik som for eksempel ved diabetes, er sentral for livskvalitet og for prognose. Dette innebærer at vi ikke bare kan rette oppmerksomheten mot den syke kroppen, men også mot personen som skal ta vare på den. Vi må se hva han eller hun trenger for å følge opp behandling, kanskje endre livsstil og komme i gang med trening. Et godt verktøy for å lykkes med dette er kommunikasjon. God kommunikasjon med pasienten gir færre klagesaker (1), bedre pasienttilfredshet og etterlevelse (2) og bedre behandling, mestring og helse $(3,4)$.

Gjennom Prosjekt klinisk helsepsykologi, støttet av ExtraStiftelsen Helse og rehabilitering og Helsedirektoratet, har Diakonhjemmet Sykehus kunnet tilby kurs i klinisk kommunikasjon for leger. I denne artikkelen vil vi beskrive arbeidet med å implementere kommunikasjonskurset «Fire gode vaner» $i$ en travel sykehushverdag.

\section{Fire gode vaner}

Kurset bygger på den amerikanske helseorganisasjonen Kaiser Permanentes modell «Four habits» (5), og er tilpasset norske forhold under ledelse av professor Pål Gulbrandsen (6). Undervisningsopplegget er testet ut $\mathrm{i}$ en randomisert studie ved Akershus universitetssykehus (7). Studien viste en endring i legenes kommunikasjonsatferd i retning av mer kommunikasjon i tråd med de fire gode vanene. Bedringen ble gjenspeilt både i pasienttilfredshet og i legens opplevelse av egen mestring. Kurset baseres på at trening på enkle grunnferdigheter gjør konsultasjonen mer effektiv. De fire gode vanene er: Invester i begynnelsen, utforsk pasientperspektivet, vis empati og invester i avslutningen.
Den første vanen innebærer å bygge tillit gjennom å være høflig, til stede og henvendt til pasienten, samtidig som man skaffer seg en oversikt over det helseproblemet pasienten kommer med. Legen innleder med åpne spørsmål for å få tak i hva pasienten har på hjertet og lager sammen med pasienten en agenda som gir rammer for konsultasjonen og for hva som skal prioriteres. Her er det viktig å sjekke ut pasientens egne forventninger til konsultasjonen.

Den andre vanen dreier seg om å få tak i pasientens egne forestillinger, tanker og måter å forstå helseplagene på samt å prøve å få tak i hvordan dette griper inn i hverdagslivet. Legen må spørre konkret om

\section{«God kommunikasjon med pasienten gir færre klagesaker»}

pasientens egne tanker og hvordan han eller hun forstår årsaken til plagene. Etterspør gjerne også pårørendes forståelse, uavhengig av om han eller hun er til stede.

Den tredje vanen går ut på å vise empati, være følelsesmessig til stede, få tak i pasientens følelser og gjennom ord og kroppsspråk validere pasientens opplevelse. Legen må se og lytte etter pasientens følelser eller hint som gis verbalt eller uten ord. Det fordrer øyekontakt og at man er oppmerksom på egne følelsesmessige reaksjoner.

Gjennom den fjerde gode vanen søker man å gi relevant informasjon, involvere pasienten i beslutningene og sjekke ut hva som eventuelt kan hindre etterlevelse. Her må man forklare grunnen til at ulike prøver tas, mulige bivirkninger samt sjekke ut om pasienten har forstått informasjonen, noe som er spesielt krevende ved alvorlig sykdom og dårlig prognose. Denne siste vanen innebærer å anerkjenne pasientens egne ressurser. Det er tross alt pasienten som skal etterleve behandlingen, kanskje legge om sin livsstil, endre vaner, holde motivasjonen vedlike og mestre hverdagen. At legen anerkjenner både selve utfordringen og pasientens ressurser til å mestre, fremmer etterlevelse av de råd som gis.

I en omfattende oversikt over forskningslitteraturen konkluderes det med at kommunikasjonstrening må inneholde egenakti- vitet med tilbakemeldinger over minst én hel dag for å gi effekt (8), mens i en oversikt over kommunikasjonstrening innen onkologi anbefales tre dager (eller mer) for å sikre atferdsendring hos deltakerne (9).

\section{Erfaringer fra modellen}

Ved Diakonhjemmet Sykehus har Fire gode vaner-kursene vært avholdt én gang per semester siden 2012, og det er hittil gjennomført fire kurs. Kursledere har gjennomgått to dagers opplæringskurs, og en psykologspesialist/psykiater og en overlege har sammen kurslederansvar for en gruppe. Vi får tilbakemeldinger fra deltakerne om at kurset oppleves nyttig og gir konkrete verktøy inn i arbeidshverdagen. Vektleggingen av klinisk kommunikasjon passer godt inn i sykehusets langsiktige arbeid med verdier, kvalitet og pasientsikkerhet. Forankringen i sykehusets verdier, og ikke minst hos direktør og ledergruppe, har vært avgjørende. Dessuten har lokal forankring av kursledere og klinikknærhet vært viktig. Alle de tre kliniske avdelingene ved sykehuset har bidratt med hver sin overlege som kursleder. Vi opplever at kurset holdes levende også mellom selve kursdagene, når både kursledere og deltakere på kurset ser hverandre i gangene på sykehuset og jobber sammen til daglig. Det gir et annet eierskap til temaet kommunikasjon enn om kursene var et «produkt» kjøpt av en ekstern leverandør.

I tillegg har det vært viktig at kursopplegget var prøvd ut ved et annet norsk sykehus med dokumentert effekt og at kursene er spesielt tilpasset leger. Kurset søkes om å være meritterende med valgfrie timer til de aktuelle spesialitetene. Trening i kommunikasjonsferdigheter har tatt utgangspunkt i kjente og til dels selvopplevde legepasient-møter. Vi tror dette fremmer opplevelsen av relevansen og nytten $i$ egen arbeidshverdag. Implementering i klinisk praksis er et kontinuerlig og utfordrende arbeid. Diakonhjemmet Sykehus har valgt å prioritere kommunikasjon gjennom å fortsette med Fire gode vaner-kursene for legene og samtidig utvide med tverrfaglige kommunikasjonskurs.

\section{Ingrid Hyldmo}

ingrid.hyldmo@diakonsyk.no

Elin Fjerstad

Ásgeir Bragason

Anders Husby

Nina Lang 


\section{Anette Hylen Ranhof \\ Sigrid Ødegård \\ Arnstein Finset}

Ingrid Hyldmo (f. 1969) er psykologspesialist ved Enhet for psykiske helsetjenester i somatikken, Diakonhjemmet Sykehus.

Forfatter har fylt ut ICMJE-skjemaet og oppgir ingen interessekonflikter.

Elin Fjerstad (f. 1964) er psykologspesialist ved Enhet for psykiske helsetjenester i somatikken og Nasjonal behandlingstjeneste for revmatologisk rehabilitering, Diakonhjemmet Sykehus. Forfatter har fylt ut ICMJE-skjemaet og oppgir ingen interessekonflikter.

Ásgeir Bragason (f. 1959) er spesialist i psykiatri og overlege ved Enhet for psykiske helsetjenester i somatikken, Diakonhjemmet Sykehus. Forfatter har fylt ut ICMJE-skjemaet og oppgir ingen interessekonflikter.

Anders Husby (f. 1964) er spesialist i generell kirurgi og i gastroenterologisk kirurgi og overlege ved Kirurgisk avdeling, Diakonhjemmet Sykehus.

Forfatter har fylt ut ICMJE-skjemaet og oppgir ingen interessekonflikter.

Nina Lang (f. 1969) er psykologspesialist ved Enhet for psykiske helsetjenester i somatikken, Diakonhjemmet Sykehus.

Forfatter har fylt ut ICMJE-skjemaet og oppgir ingen interessekonflikter.
Anette Hylen Ranhoff (f.1956) er spesialist $\mathrm{i}$ indremedisin og i geriatri, overlege ved Medisinsk avdeling, Diakonhjemmet Sykehus og professor i geriatri ved Universitetet i Bergen. Forfatter har fylt ut ICMJE-skjemaet og oppgir ingen interessekonflikter.

Sigrid Ødegård (f. 1962) er spesialist i revmatologi, ph.d., og seksjonsoverlege ved Nasjonal behandlingstjeneste for revmatologisk rehabilitering, Revmatologisk avdeling, Diakonhjemmet sykehus.

Forfatter har fylt ut ICMJE-skjemaet og oppgir ingen interessekonflikter.

Arnstein Finset (f. 1947) er dr. philos. og professor ved Avdeling for medisinsk atferdsforskning, Institutt for medisinske basalfag. Universitetet i Oslo.

Forfatter har fylt ut ICMJE-skjemaet og oppgir følgende interessekonflikter: Han har mottatt honorar fra Diakonhjemmet Sykehus for Fire gode vaner-kurs.

\section{Litteratur}

1. Levinson W, Roter DL, Mullooly JP et al. Physicianpatient communication. The relationship with malpractice claims among primary care physicians and surgeons. JAMA 1997; 277: 553-9.

2. Zolnierek KB, Dimatteo MR. Physician communication and patient adherence to treatment: a meta-analysis. Med Care 2009; 47: 826-34.

3. Stewart MA. Effective physician-patient communication and health outcomes: a review. CMAJ 1995 152: $1423-33$

4. Finset A. How communication between clinicians and patients may impact pain perception. I: Col-
Loca L, Flaten MA, Meissner K red. Placebo and pain. Amsterdam: Elsevier, 2013: 1003-15.

5. Frankel RM, Stein T. Getting the most out of the clinical encounter: the four habits model. J Med Pract Manage 2001: 16: 184-91.

6. Gulbrandsen P, Krupat E, Benth JS et al. «Four Habits» goes abroad: report from a pilot study in Norway. Patient Educ Couns 2008; 72: 388-93.

7. Fossli Jensen B, Gulbrandsen P. Dahl FA et al. Effectiveness of a short course in clinical communication skills for hospital doctors: results of a crossover randomized controlled trial (ISRCTN22153332). Patient Educ Couns 2011; 84: $163-9$

8. Berkhof M, van Rijssen HJ, Schellart AJM et al. Effective training strategies for teaching communication skills to physicians: an overview of systematic reviews. Patient Educ Couns 2011; 84: 152-62.

9. Barth J, Lannen P. Efficacy of communication skills training courses in oncology: a systematic review and meta-analysis. Ann Oncol 2011; 22: $1030-40$

Mottatt 4.4. 2014, første revisjon innsendt 13.6. 2014, godkjent 24.9. 2014. Redaktør: Kari Tveito.

Publisert først på nett. 